\title{
Iron localization in Acarospora colonizing schist on Signy Island
}

\author{
O.W. PURVIS ${ }^{1,2}$, P. CONVEY ${ }^{3}$, M.J. FLOWERDEW ${ }^{3}$, H.J. PEAT ${ }^{3}$, J. NAJORKA ${ }^{1}$ and A. KEARSLEY ${ }^{1}$ \\ ${ }^{I}$ Natural History Museum, Cromwell Rd, London SW7 5BD, UK \\ ${ }^{2}$ Camborne School of Mines, College of Engineering, Mathematics and Physical Sciences, University of Exeter, Cornwall Campus, \\ Penryn TR10 9EZ, UK \\ ${ }^{3}$ British Antarctic Survey, NERC, High Cross, Madingley Road, Cambridge CB3 OET, UK \\ owpurvis@gmail.com
}

\begin{abstract}
A small, inconspicuous lichen, Acarospora cf. badiofusca, was discovered colonizing ironstained quartz mica schists on the lower slope of Manhaul Rock, a recently exposed nunatak on the McLeod Glacier, Signy Island, South Orkney Islands. Thallus colour ranged from rust on exposed rock surfaces to paler orange and green in shaded crevices. This study addressed the hypothesis that colour reflects element localization, and considered substance localization within lichen tissues and responses to stress. Electron microprobe analysis of specimens confirmed that $\mathrm{Fe}$ is localized principally in the outer rust-coloured part of the cortex, confirming that the colour reflects Fe localization. Oxalates, widely reported as contributing to tolerance mechanisms to environmental stress, were not detected using X-ray diffraction. The upper thallus surface consisted of sub-micron particulate phases containing $\mathrm{Fe}, \mathrm{Al}$ and $\mathrm{O}$, suggesting mixed oxide/ hydroxide phases are present and play a role in photoprotection.
\end{abstract}

Received 16 December 2011, accepted 27 March 2012, first published online 8 October 2012

Key words: adaptation, lichen, Maritime Antarctic, recent colonist, rust

\section{Introduction}

Lichen dominated vegetation covers approximately $6 \%$ of the Earth's land surface. Lichens are dominant in certain polar ecosystems, primary colonists of rocks, play a major role in the biogeochemical cycling of elements and contribute to soil formation (Øvstedal \& Smith 2001, Haas \& Purvis 2006, Nash 2008). Mountain ecosystems and cold deserts are especially rich in lichens and provide excellent field laboratories to study their biology under various stress conditions (Hafellner et al. 2010). Many lichens are colourful, mostly due to the presence of over 700 secondary metabolites which are of fungal origin (Huneck \& Yoshimura 1996). Colours become less intense in shaded habitats and (in the Northern Hemisphere) during winter months (Gauslaa \& McEvoy 2005).

For many years the ecological importance and possible evolutionary significance of the chemical components of the upper cortex in lichens has been underestimated. In lichens growing on exposed substrata, various lightabsorbing compounds are located in the upper cortical tissue of the vegetative and generative parts of the thallus, which often show variation in concentration along light gradients over space and time (Elix \& Stocker-Wörgötter 2008). An obvious effect of mineralization on lichens is the strong rust colour of certain species, widely considered to reflect a mechanism to avoid toxicity (Lange \& Ziegler 1963). Rust-coloured or 'oxydated' lichens occur in many different and unrelated lichenized groups, one of which is the genus Acarospora s.l. (Lange \& Ziegler 1963,
Hertel 1988, Purvis \& Pawlik-Skowrońska 2008). Species belonging to Acarospora s.l. thrive in extreme terrestrial habitats, tolerating stressful $\mathrm{pH}$ conditions (Wirth 1972), high nutrient concentrations (e.g. around bird perches and penguin colonies in the Antarctic) or osmotic stresses (e.g. in the supralittoral environment) (Øvstedal \& Smith 2001). Others tolerate both natural (e.g. growing near the volcano Mount Vesuvius, Italy) and anthropogenic pollutant sources (Wedin et al. 2009).

A single iron phase has so far been characterized in rustcoloured lichens, notably aluminium-containing goethite in Lecidea dicksonii (J.F. Gmel.) Ach. (= Tremolechia atrata (Ach.) Hertel), using analytical transmission electron microscopy (Jones et al. 1981). By far the greatest research effort into characterizing iron minerals associated with lichens concerns those occurring in the substratum beneath them, research driven partly from a desire to understand weathering processes. These include ferric oxalate (Ascaso et al. 1982), $\mathrm{Fe}(\mathrm{III})$ oxyhydroxides, often associated with a matrix of mucopolysaccharide gel (Barker \& Banfield 1996, Adamo et al. 1997), ferrihydrite beneath Antarctic cryptoendolithic lichens (Johnston \& Vestal 1993), iron hydroxide nanocrystals associated with Antarctic chasmoendolithic hyphae (Wierzchos et al. 2003), birnessite, 'desert varnish' (MnO and $\mathrm{FeO}$ ) (Fomina et al. 2006) and amorphous silica coated by Fe staining (Haas \& Purvis 2006). Mixed iron phases may be present in other species belonging to Acarospora s.l. (Purvis et al. 2008a, 2008b).

Signy Island is one of the South Orkney Islands, lying in the Maritime Antarctic $900 \mathrm{~km}$ south-west of sub-Antarctic 


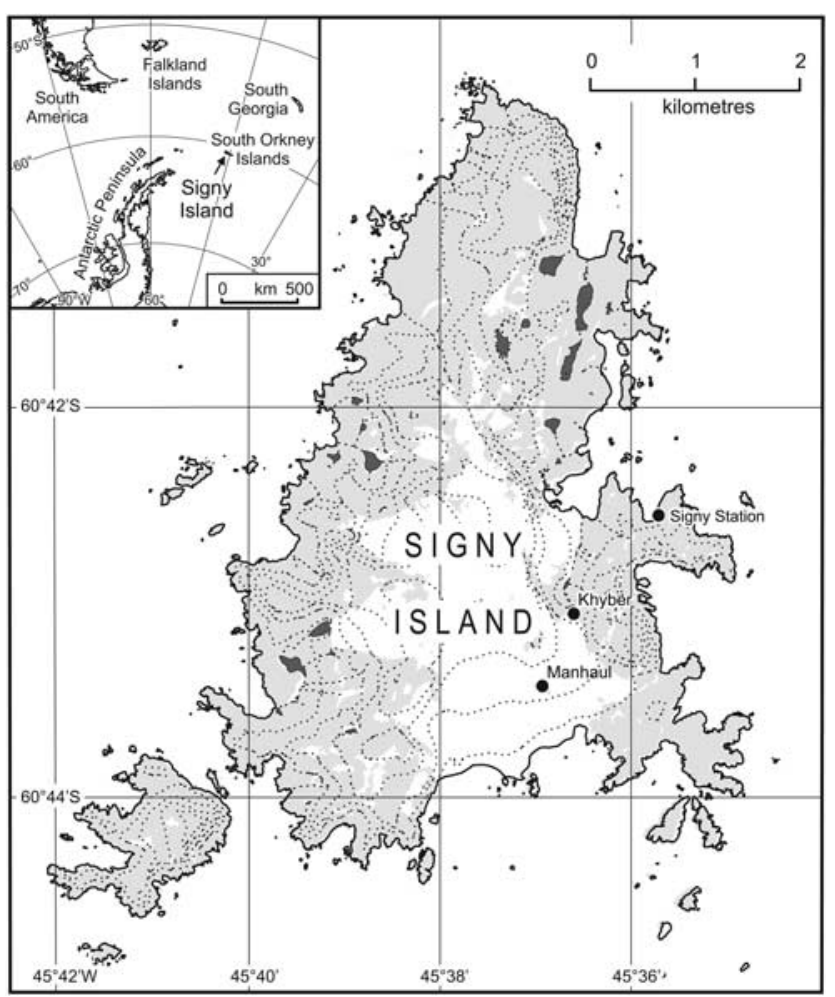

Fig. 1. Locality map showing Manhaul Rock in relation to Khyber Pass and BAS Signy Station.

South Georgia. It is mountainous with an ice cap, glaciers, rugged topography, and a complex geology and pedology, which provide a wide range of terrestrial habitats (Smith 1990). In spite of its small size $(8 \times 5 \mathrm{~km})$ it possesses the greatest terrestrial biological diversity discovered so far of any sites of comparable size in the Antarctic, with over $50 \%$ of the lichens known in Antarctica being recorded (Smith 2007). Signy Island probably experiences greater fluctuations in climate than most other comparable localities in Antarctica (Smith 1990). Superimposed on this, mean summer temperatures have increased strongly over the past 50 years (Smith 1990, Quayle et al. 2002). As a consequence of the rapid warming and glacial retreat, new areas of rock and ground are being exposed, providing opportunities for lichen colonization.

Using the opportunity provided by the discovery of recently colonizing thalli of the lichen genus Acarospora, the current study aimed to: i) address the hypothesis that thallus colour reflects element localization, and ii) consider element and substance localization in its tissues.

\section{Materials and methods}

\section{Study location}

The study location, Manhaul Rock, was entirely covered by the McLeod Glacier as recently as 50 years ago (Fig. 1).
Situated in the southern central region of the McLeod Glacier, neither the geological map (Matthews \& Maling 1967) nor British Antarctic Survey aerial photographs (1968) show Manhaul Rock exposed, although a rocky knoll was reported in 1963 which by 1988 protruded over $8 \mathrm{~m}$ above the ice and covered an area of 0.5 ha (Smith 1990). A field visit to Manhaul Rock was made on 16 November 2009 when Acarospora cf. badiofusca (Nyl.) Th. Fr. (Øvstedal \& Smith 2001) was first discovered growing more or less perpendicular to the mineral cleavage plane on weathered iron-stained schistose rocks (Collection S2_8, O.W. Purvis \& B. Maltman, 16 November 2009 (BAS)) (Fig. 2a \& b). Colours ranged from rust-coloured in exposed situations to green in shaded crevices.

\section{Geology}

Signy Island forms part of the Scotia Metamorphic Complex (Tanner et al. 1982). This complex comprises Permian-Triassic continental elements of predominantly semi-pelite juxtaposed with oceanic elements. These include pelite, marble, metachert and metabasites with an enriched-type MORB and alkaline ocean-island basalt chemistry (Storey \& Meneilly 1985), which were accreted onto the continent margin during an episode of subduction in the Early Jurassic (Flowerdew et al. 2007). Epidote amphibolites-facies metamorphic conditions of c. $545^{\circ} \mathrm{C}$ at $8 \mathrm{kbar}$ that were attained during accretion (Storey \& Meneilly 1985) led to the widespread growth of garnet and biotite in the pelitic lithologies and garnet, amphibole and epidote in the basaltic protoliths.

An oceanic element of the Scotia Metamorphic Complex is exposed at Manhaul Rock. Structurally, pelite and semipelite with garnet porphyroblasts form most of the flat elevated surfaces of the rock exposure. Structurally lower units, at the rock-ice interface and also forming the western cliff face of the exposure, are more calcareous containing amphibole- and garnet-bearing pelite with metre-thick marble bands and thinner biotite- and amphibole-bearing metabasite. Lichens described in this study were collected exclusively from the structurally higher unit.

\section{Scanning electron microscopy and electron probe microanalysis}

Element localization in lichens is usually investigated through a combination of spot analyses and X-ray element mapping of natural and resin-embedded samples and in back-scattered electron (BSE) mode, where the intensity of BSE is proportional to the average atomic number of the elements present (Jones et al. 1981, Williamson et al. 1998). Secondary products and pigments are routinely localized in lichens using light microscopy and scanning electron microscopy, and, more rarely, using laser microprobe Fourier transform mass spectrometry 

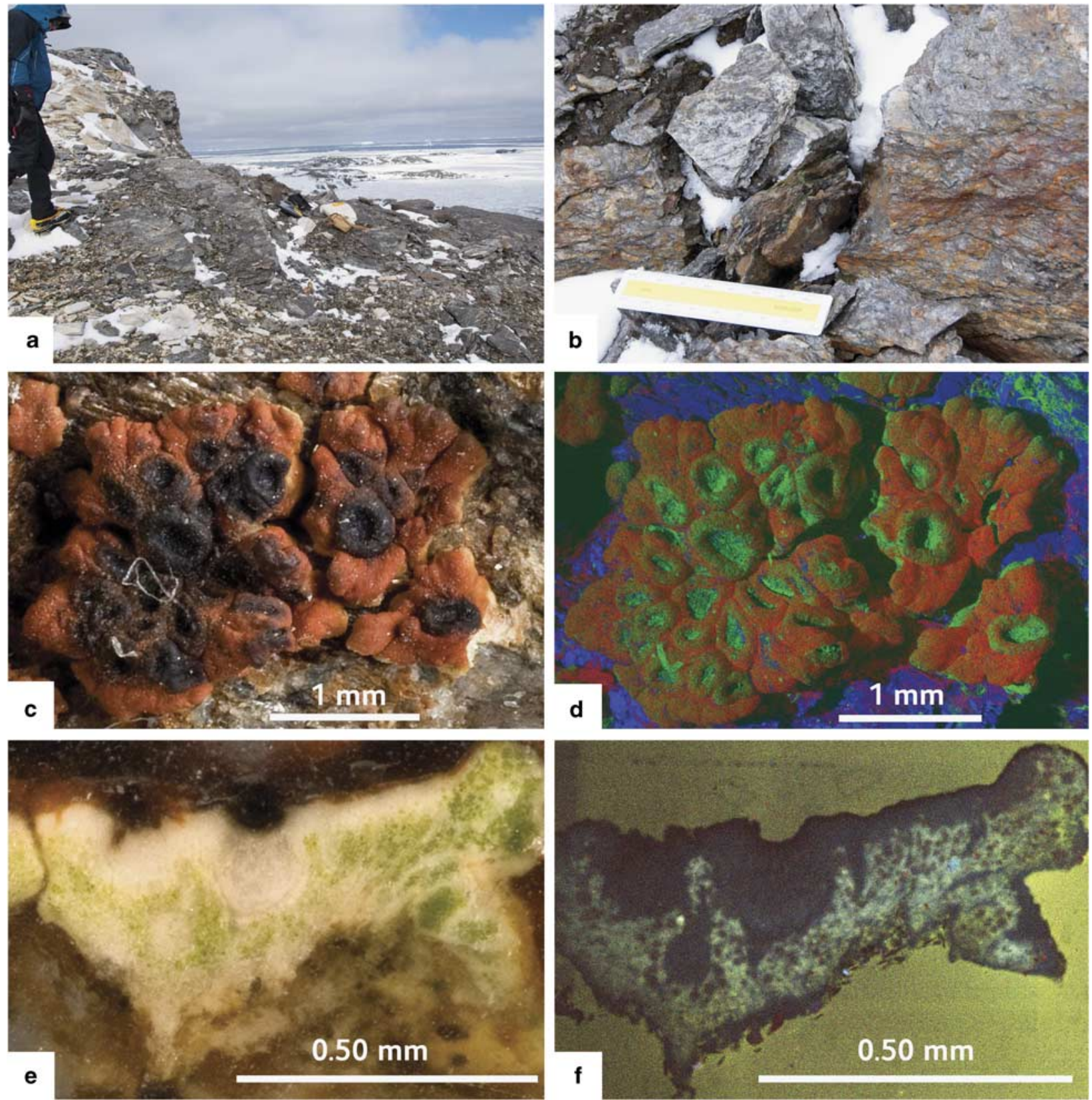

Fig. 2. a. Sampling site. Lower slope of Manhaul Rock, 16 November 2009. b. Fe-stained schists colonized by Acarospora, 16 November 2009. Scale $=15 \mathrm{~cm}$. c. Close-up of Acarospora colonizing schist bearing black apothecia. d. X-ray element map of Acarospora thallus shown in c., orange-red $=\mathrm{Fe}$, green $=\mathrm{C}$, blue $=\mathrm{Si}$. e. Resin-embedded section showing superficial brown pigmented layer and photobiont cells (green) arranged in more or less vertical arrays. f. Cathodoluminescence image (red, blue, green).

employing cathodoluminescence (Mathey et al. 1994) and Raman spectroscopy (Holder et al. 2000).

Sample S2_8 was studied using three different preparation methods and two SEMs: i) transverse sections through areoles and the lichen-rock interface were prepared using a razor blade and fine tweezers to prevent smearing and both sections and areoles mounted with double-sided tape on an aluminium stub. These were examined in a
LEO 1455 variable pressure SEM utilizing a BSE detector, operated at $15 \mathrm{kV}$ and an energy dispersive (EDX) detector, ii) four areoles (dried for one week at $30^{\circ} \mathrm{C}$ ) were mounted in a Specifix 20 resin block. Blocks were ground and lapped on a 1000 - down to a 2500 -silicon carbide grit to reveal a suitable transverse section through each areole. Grinding and lapping were carried out dry to avoid hydraulic undercutting (scooping out) of the relatively 

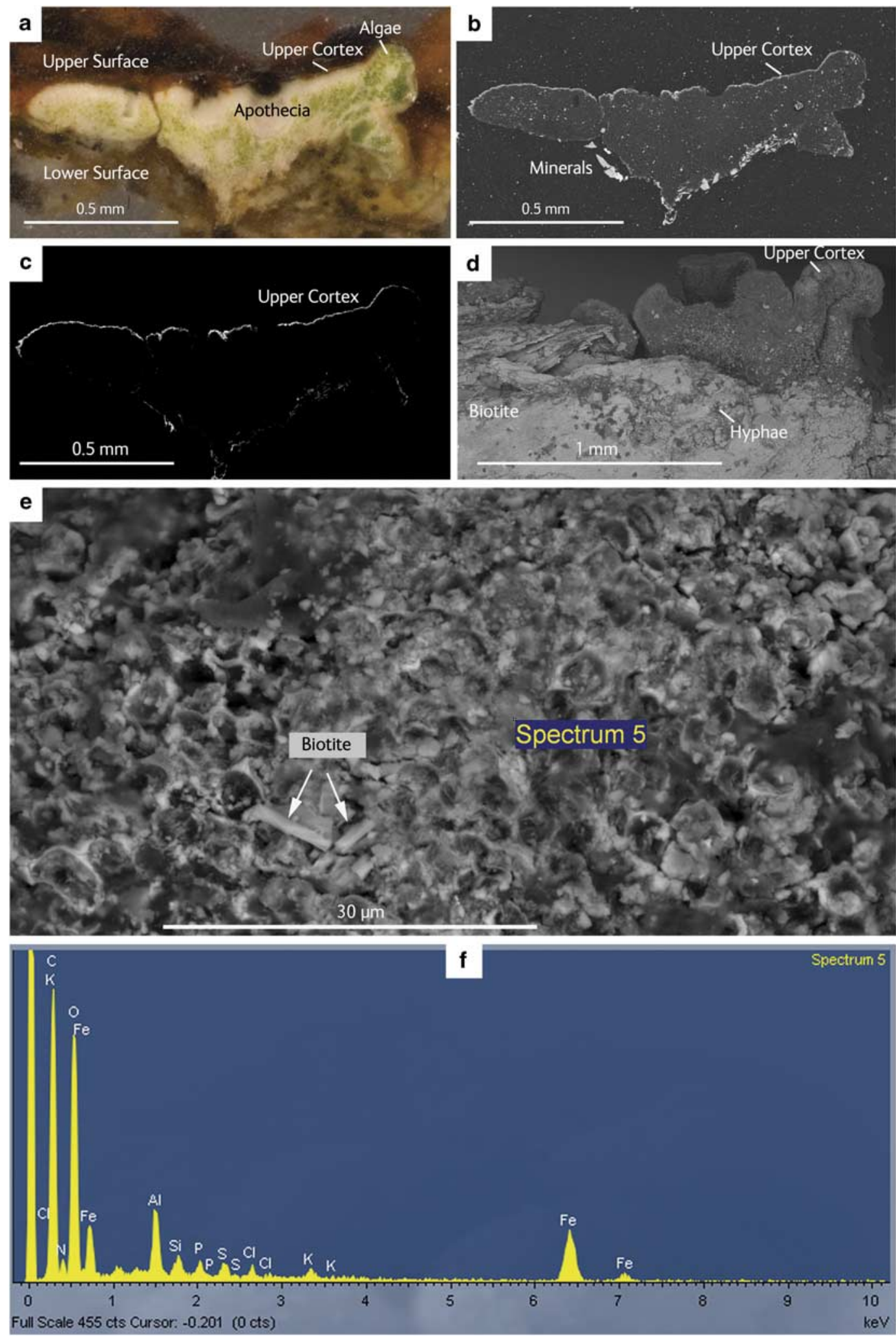

Fig. 3. a. Resin-embedded section showing superficial brown pigmented layer and photobiont cells (green) arranged in more or less vertical arrays. b. SEM back-scattered electron (BSE) image of resin embedded section. c. X-ray element mapping (Fe). Resin embedded section. d. SEM BSE image of natural cleavage across lichen-rock interface. e. Close-up of surface showing amorphous or microbotryoidal granules and biotite grains. f. X-ray spectra of thallus surface where biotite grains were not visible (spectrum 5). 
soft organic material and to prevent leaching of mobile elements from the organics. The lap was washed and dried at regular $(30 \mathrm{~s})$ intervals to prevent a build-up of mineral dust ('mill flour') during polishing that can cause undercutting and may also result in contamination of the lichen. The polishing produced a flat surface suitable for energy dispersive X-ray spectroposcopy (EDX) (Williamson et al. 1998, Purvis et al. 2008a, 2008b). Macrophotography of the lichen growing directly on the rock and the embedded sample was undertaken. Polished resin blocks of the embedded lichen sample were prepared for analytical scanning electron microscopy (SEM), the blocks were carbon coated prior to imaging and analysis using a Zeiss EVO 15 LS SEM and Oxford Instruments INCA EDX. Images were captured using a solid state 4-quadrant back scattered electron detector to show differences in elemental contrast. Energy dispersive X-ray analysis was applied to collect elemental maps and illustrate the distribution of $\mathrm{Fe}, \mathrm{C}$ and $\mathrm{Si}$. A third generation variable pressure secondary detector was used as a panchromatic cathodoluminescence detector, also utilizing SmartStitch image acquisition and montage creation software.

\section{$X R D$ investigation}

The XRD analysis of the lichen and its mineral substratum was performed directly on the schist sample without separating material from the rock. The material was studied on a microdiffraction system equipped with a GeniX Cu High Flux X-ray source and a FOX 2D 10_30P mirror. The system delivers a high-brightness microbeam (beam diameter $230 \mu \mathrm{m}$ ) of copper $\mathrm{K}$ alpha radiation. Operating conditions of the X-ray source were $50 \mathrm{kV}$ and $1 \mathrm{~mA}$. Rapid data acquisition was achieved by using an INEL $120^{\circ}$ curved position sensitive detector (PSD). Diffracted intensities were collected in flat-plate asymmetric reflection geometry without angular movement of tube, sample and detector. The angular linearity of the PSD was calibrated using the external standards silver behenate and silicon (NIST SRM 640) and full 2-Theta linearization of the PSD was performed with a least-squares cubic spline function. To minimize mixed analysis of lichens and the underlying mineral substratum, lichen analysis concentrated on areas where lichens were clearly exposed from the surface.

\section{Results}

The lichen was rust coloured apart from the black carbonized fruiting bodies (apothecia) producing spores (Fig. 2c). In section, the upper part of the cortex was rust coloured, and the medulla white with green algae arranged in more or less vertical arrays (Fig. 2e).

\section{SEM investigation}

The upper surface consisted of irregular shaped grain accumulations with particle sizes in the sub-micron scale and scattered biotite grains (Fig. 3e). In section (backscattered mode) the upper part of the cortex was generally brighter than the rest of the thallus apart from scattered mineral grains and other minerals attached to its lower surface (Fig. 3b \& d). Oxalates were not observed. Spot analyses of surface mineral grains confirmed that mainly $\mathrm{Fe}, \mathrm{Al}$ and $\mathrm{O}$ were present (Fig. 3f), suggesting mixed oxide/hydroxide phases are present. X-ray element mapping confirmed the lichen was enriched in Fe relative to the rock surface (Si-rich), apart from the fruiting bodies (apothecia) producing spores which are rich in $\mathrm{C}$ (Fig. 2d), and that Fe was localized principally in the outer rust-coloured part of the cortex (Fig. 3a \& c). Cathodoluminescence was restricted to the medulla and not observed in algae, apothecia (fruiting bodies) or cortex (Fig. 2f).

\section{XRD investigation}

The presence of mica was confirmed in the substratum. No crystalline substances, including calcium oxalate and other lichen substances, were detected in the lichen.

\section{Discussion}

X-ray microanalysis of the surface of $A$. cf. badiofusca (in both untreated and embedded samples) confirmed that $\mathrm{Fe}$ was localized principally in the outer rust-coloured part of the cortex, supporting the hypothesis that the rust colour indicates $\mathrm{Fe}$ localization. This is consistent with previous studies investigating rust-coloured Acarospora taxa using electron probe microanalysis in the Harz Mountains, Germany (Noeske et al. 1970), and in Scandinavia (Purvis et al. 2008a) and Wales (Purvis et al. 2008b). Fe is a major component of chemical and biological processes (Taylor \& Konhauser 2001) and is presumably present as $\mathrm{Fe}^{3+}$, as indicated by the surface lichen colour and because of the oxidizing environment. $\mathrm{Fe}^{3+}$ has been reported previously in different species of Acarospora from the Harz Mountains in Germany (Lange \& Ziegler 1963). XRD analysis implies that the surface rust-coloured layer in the lichen may not be in a crystalline state, or that the crystallite size of any crystalline phase would have to be extremely small, below the X-ray coherent scattering domain size (i.e. a few tens of unit cells).

Several lichen species (but not Acarospora) are known to survive and photosynthesize beneath snow, although light penetration falls off with increasing depth and respiration may result in net carbon loss (Green et al. 2008). In the case of Acarospora growing in exposed, well-illuminated sites, Fe-pigmented surfaces also limit light reaching 
potentially sensitive lichen photobionts (Purvis et al. 2008a, 2008b). An analogous form of protection has been suggested for cryptoendolithic lichens shielded by iron oxide encrusted sandstone rocks at East Beacon, Victoria Land (Friedmann 1982, Edwards et al. 2004).

Photographic monitoring on Signy Island confirms that lichen colonization may proceed rapidly where conditions are favourable, especially close to the shore and vertebrate colonies, both sources for nutrients. Sites in more montane habitats are colonized much more slowly by nitrophobous and halophobous lichens and occasionally mosses (Smith 1990). The discovery of Acarospora in close proximity to the McLeod Glacier, on rocks which at first sight appeared to be devoid of lichen growth, was unexpected. The edge of a retreating glacier is likely to be an extreme and stressful environment and, with seasonal snow cover, also a dynamic and variable habitat. Snow depth influences its insulating capacity, light penetration and the hydrological reservoir, a source of nutrients and chemicals, all factors on which organisms rely or are otherwise influenced by during growth and reproduction (Jones et al. 2001). No studies on the ecophysiology of Acarospora s.l. in polar regions have been attempted, but in terms of vegetation strategies, Acarospora cf. badiofusca is a stress tolerator sensu Grime (1979).

The most tangible element of a lichen's environment is its substratum. In a mycological context, the substratum is often assumed to provide nutrition. However, whilst lichens clearly have substratum 'preferences', their role in nutrition is largely conjectural (Brodo 1973, Brown 1976, Nash 2008). Crustose lichens, including Acarospora, are attached to the substratum by hyphae arising from within the medulla forming rhizines. Rhizine penetration often follows lines of weakness, e.g. mica cleavage planes in granites (Syers \& Iskandar 1973), as was observed in the present study. Direct mechanical degradation of minerals associated with the invasive abilities of fungi may be supplemented by biochemical weathering leading to mineral dissolution and a potential supply of essential cations for the fungus (Fomina et al. 2006). Preferential dissolution of intercalary cations from biotite occurs in the presence of microorganisms (Hopf et al. 2009). Layered silicates provide a potential nutritional source.

Why the medulla shows cathodoluminesence is unknown. Neither calcium oxalates, widely reported as contributing to tolerance mechanisms to environmental stress, nor other lichen substances were detected by X-ray diffraction in the lichen, as established previously in Acarospora s.l. sampled from Sweden (Purvis et al. 2008a) and Wales (Purvis et al. 2008b). The lichen's occurrence in this extreme habitat suggests the use of a complex combination of mechanisms to avoid or mitigate environmental stress. Future study of such species even has the potential to shed new light on the investigation of the existence of life on other planets, for instance through evidence provided by 'biosignatures' left in previously colonized rocks (Wynn-Wiliams et al. 2002, Wierzchos et al. 2003).

\section{Acknowledgements}

We acknowledge funding from the NERC Antarctic Funding Initiative Collaborative Gearing Scheme (ref. CGS11/57). We are very grateful to Bruce Maltman for field assistance, Phil Hurst (NHM Image Resources) for macrophotography (Figs 2c, 2e \& 3a), Tony Wighton for sample preparation and Verity Clarkson, Armando Mendez and Falko Langenhorst (Friedrich-Schiller-Universität Jena) for helpful assistance with literature. We thank Ulrik Søchting and an anonymous referee for useful comments on the manuscript.

\section{References}

Adamo, P., Colombo, C. \& Violante, P. 1997. Iron oxides and hydroxides in the weathering interface between Stereocaulon vesuvianum and volcanic rock. Clay Minerals, 32, 453-461.

Ascaso, C., Galvan, J. \& Rodriguez-Pascual, C. 1982. The weathering of calcareous rocks by lichens. Pedobiologia, 24, 219.

BARKER, W.W. \& BANFIELD, J.F. 1996. Biologically versus inorganically mediated weathering reactions: relationships between minerals and extracellular microbial polymers in lithobiontic communities. Chemical Geology, 132, 55-69.

Brodo, I.M. 1973. Substrate ecology. In Ahmadjian, V., ed. The lichens. New York: Academic Press, 401-441.

Brown, D.H. 1976. Mineral uptake by lichens. In Brown, D.H., Hawksworth, D.L. \& Bailey, R.H., eds. Lichenology: progress and problems. London: Academic Press, 419-439.

Edwards, H.G.M., Wynn-Williams, D.D. \& Villar, S.E.J. 2004. Biological modification of haematite in Antarctic cryptoendolithic communities. Journal of Raman Spectroscopy, 35, 470-474.

Elix, J.A. \& Stocker-Wörgötter, E. 2008. Biochemistry and secondary metabolites. In NASH III, T.H., ed. Lichen biology. Cambridge: Cambridge University Press, 104-133.

Flowerdew, M.J., Daly, J.S. \& Riley, T.R. 2007. New Rb-Sr mineral ages temporally link plume events with accretion at the margin of Gondwana. In Cooper, A.K. \& Raymond, C.R., eds. Antarctica: a keystone in a changing world - Online Proceedings of the 10th ISAES, USGS Open-File Report 2007-1047, Short Research Paper 012, 10.3133/of2007-1047.srp012.

Fomina, M.A., Burford, E.P. \& Gadd, G.M. 2006. Fungal dissolution and transformation of minerals: significance for nutrient and metal mobility. In GADD, G.M., ed. Fungi in biogeochemical cycles. Cambridge: Cambridge University Press, 236-266.

FriedmanN, E.I. 1982. Endolithic microorganisms in the Antarctic cold desert. Science, 215, 1045-1053.

GauslaA, Y. \& McEvoy, M. 2005. Seasonal changes in solar radiation drive acclimation of the sun-screening compound parietin in the lichen Xanthoria parietina. Basic and Applied Ecology, 6, 75-82.

Green, T.G.A., Nash III, T.H. \& Lange, O.L. 2008. Physiological ecology of carbon dioxide exchange. In NASH III, T.H., ed. Lichen biology. Cambridge: Cambridge University Press, 152-181.

Grime, J.P. 1979. Plant strategies and vegetation processes. Chichester: John Wiley, 222 pp.

HaAs, J.R. \& Purvis, O.W. 2006. Lichen biogeochemistry. In GadD, G.M., ed. Fungi in biogeochemical cycles. Cambridge: Cambridge University Press, 344-376.

Hafellner, J., Kärnefelt, I. \& Wirth, V., eds. 2010. Diversity and ecology of lichens in polar and mountain ecosystems. Stuttgart: J. Cramer in der Gebrüder Borntraeger Verlagsbuchhandlung, 389 pp. 
Hertel, H. 1988. Problems in monographing Antarctic crustose lichens. Polarforschung, 58, 65-76.

Holder, J.M., Wynn-Williams, D.D., Perez, F.R. \& Edwards, H.G.M. 2000. Raman spectroscopy of pigments and oxalates in situ within epilithic lichens: Acarospora from the Antarctic and Mediterranean. New Phytologist, 145, 271-280.

Hopf, J., Langenhorst, F., Pollok, K., Merten, D. \& Kothe, E. 2009. Influence of microorganisms on biotite dissolution: an experimental approach. Chemie der Erde, 69, 45-56.

Huneck, S. \& Yoshimura, I. 1996. Identification of lichen substances. Berlin: Springer, 493 pp.

Johnston, C.G. \& Vestal, J.R. 1993. Biogeochemistry of oxalate in the Antarctic cryptoendolithic lichen-dominated community. Microbial Ecology, 25, 305-319.

Jones, D., Wilson, M.J. \& McHardy, W.J. 1981. Lichen weathering of rock-forming minerals - application of scanning electron-microscopy and micro-probe analysis. Journal of Microscopy, 124, 95-104.

Jones, H.G., Pomeroy, J.W., Walker, D.A. \& Hoham, R.W., eds. 2001. Snow ecology: an interdisciplinary examination of snow-covered ecosystems. Cambridge: Cambridge University Press, 378 pp.

LANGe, O.L. \& Ziegler, H. 1963. Der Schwermetallgehalt von Flechten aus dem Acarosporetum sinopicae auf Erzschlackenhalden des Harzes. I. Eisen und Kupfer. Mitteilungen der Floristisch-soziologischen Arbeits gemeinschaft, 10, 156-183.

Mathey, A., Dingley, D., van Vaeck, L. \& Young, R. 1994. Cathodoluminescence study of the lichen Acarospora hilaris. Journal de Physique, 13, 791-792.

Matthews, D.H. \& Maling, D.H. 1967. The geology of the South Orkney Islands. 1. Signy Island. Falkland Islands Dependencies Survey Scientific Reports, No. 25, 32 pp.

NASH III, T.H. 2008. Lichen biology, 2nd ed. Cambridge, Cambridge University Press, 486 pp.

Noeske, O., Läuchli, A., Lange, O.L., Vieweg, G.H. \& Ziegler, H. 1970. Konzentration und Lokalisierung von Schwermetallen in Flechten der Erzschlackenhalden des Harzes. Deutsche Botanische Gesellschaft Neue Folge, 4, 67-79.

Øvstedal, D.O. \& SMith, R.I.L. 2001. Lichens of Antarctica and South Georgia: a guide to their identification and ecology. Cambridge: Cambridge University Press, 411 pp.

Purvis, O.W. \& Pawlik-Skowrońska, B. 2008. Lichens and metals. In Avery, S.V., Stratford, M. \& van West, P., eds. Stress in yeasts and filamentous fungi. Amsterdam: Elsevier, 175-200.

Purvis, O.W., Kearsley, A., Cressey, G., Crewe, A.T. \& Wedin, M. 2008a. Mineralization in rust-coloured Acarospora. Geomicrobiology Journal, 25, 142-148.
Purvis, O.W., Kearsley, A., Cressey, G., Batty, L.C., Jenkins, D.A., Crewe, A.T. \& Wedin, M. 2008b. Mineralization in rust-coloured Acarospora. In Chen, Z.-S., Lee, D.-Y. \& Lin, T.-S., eds. Proceedings of the 14th International Conference on Heavy Metals in the Environment. Taipei, Taiwan, November 16-23, 2008. Taiwan: Department of Agricultural Chemistry, National Taiwan University, 472-474.

Quayle, W.C., Peck, L.S., Peat, H., Ellis-Evans, J.C. \& Harrigan, P.R. 2002. Extreme responses to climate change in Antarctic lakes. Science, 295, 645.

Sмith, R.I.L. 1990. Signy Island as a paradigm of biological and environmental change in Antarctic terrestrial ecosystems. In KeRRY, K.R. \& Hempel, G., eds. Antarctic ecosystems, ecological change and conservation. Berlin: Springer, 32-50.

SмIтH, R.I.L. 2007. Half a continent in a square kilometre: the exceptional diversity of a small Antarctic island. In Kärnefelt, I. \& Thell, A., eds. Lichenological contributions in honour of David Galloway. Bibliotheca Lichenologica, 95. Stuttgart: J. Cramer, 387-403.

Storey, B.C. \& Meneilly, A.W. 1985. Petrogenesis of metamorphic rocks within a subduction-accretion terrane, Signy Island, South Orkney Islands. Journal of Metamorphic Geology, 3, 21-42.

SYERS, J.K. \& IsKANDAR, I.K. 1973. Pedogenetic significance of lichens. In Ahmadjian, V. \& Hall, M.E., eds. The lichens. London: Academic Press, 225-248.

Tanner, P.W.G., Pankhurst, R.J. \& Hyden, G. 1982. Radiometric evidence for the age of the subduction complex in the South Orkney and South Shetland Islands, West Antarctic. Journal of the Geological Society, 139, 683-690.

TAYlor, K.G. \& Konhauser, K.O. 2011. Iron in earth surface systems: a major player in chemical and biological processes. Elements, 7, 83-88.

Wedin, M., Westberg, M., Crewe, A.T., Tehler, A. \& Purvis, O.W. 2009. Species delimitation and evolution of metal bioaccumulation in the lichenized Acarospora smaragdula (Ascomycota, Fungi) complex. Cladistics, 25, 161-172.

Wierzchos, J., Ascaso, C., Sancho, L.G. \& Green, A. 2003. Iron-rich diagenetic minerals are biomarkers of microbial activity in Antarctic rocks. Geomicrobiology Journal, 20, 15-24.

Williamson, B.J., McLean, J. \& Purvis, O.W. 1998. Application of X-ray element mapping across the lichen-rock interface. Journal of Microscopy, 191, 91-96.

WIRTH, V. 1972. Die Silikatflechten - Gemeinshaften im ausseralpinen Zentraleuropa. Dissertationes Botanicae, 17, 1-306.

Wynn-Wiliams, D.D., Edwards, H.G.M., Newton, E.M. \& Holder, J.M. 2002. Pigmentation as a survival strategy for ancient and modern photosynthetic microbes under high ultraviolet stress on planetary surfaces. International Journal of Astrobiology, 1, 39-49. 